\title{
PENGARUH LINGKUNGAN FISIK DAN HEDONIC SHOPPING VALUE TERHADAP PEMBELIAN TIDAK DIRENCANAKAN DI GIANT EXPRESS CILEGON
}

\author{
Muhamad Suhaemi \\ Juliandra Muharram \\ eganjaka@yahoo.com \\ Program Studi Manajemen Fakultas Ekonomi Dan Bisnis \\ Universitas Serang Raya
}

\begin{abstract}
ABSTRAK
Penelitian ini bertujuan untuk mengetahui pengaruh Lingkungan Fisik terhadap Pembelian Tidak Direncanakan, untuk mengetahui pengaruh Hedonic Shopping Value terhadap Pembelian Tidak Direncanakan dan untuk mengetahui pengaruh Lingkungan Fisik dan Hedonic Shopping Value Terhadap Pembelian Tidak Direncanakan di Giant Express Cilegon.Penelitian ini menggunakan metode penelitian kuantitatif. Populasi dalam penelitian ini adalah konsumen Giant Express Cilegon yang pernah berbelanja di Giant Express Cilegon dan data di analisis dengan SPSS versi 20. Metode pemilihan jenis sampel yang digunakan adalah accidental sampling. Pengumpulan data dilakukan dengan menyebar kuesioner kepada 100 responden.Berdasarkan hasil penelitian dapat disimpulkan bahwa hasil Uji F menunjukkan vairabel Lingkungan Fisik dan Hedonic Shopping Value secara simultan berpengaruh signifikan terhadap Pembelian Tidak Direncanakan. Sedangkan berdasarkan hasil uji secara parsial dengan Uji t menunjukkan bahwa variabel Lingkungan Fisik berpengaruh terhadap Pembelian Tidak Direncanakan dengan tingkat signifikansi 0,000 dan Hedonic Shopping Value berpengaruh signifikansi terhadap Pembelian Tidak Direncanakan dengan tingkat signifikansi 0,000.
\end{abstract}

Kata kunci :Lingkungan Fisik, Hedonic Shopping Value, Pembelian Tidak Direncanakan

\section{ABSTRACT}

This study aims to determine the effect service scape on impulse buying, to determine the effect hedonic shoping value on impulse buying, and to determine the effect service scape and hedonic shoping value on impulse buying at giant express Cilegon. This study uses quantitative research methode population in this study is consumerswho have shoped at giant express cilegon data were analyzed with SPSS version 20. The methode of selecting type of sample used accidental sampling. Data was done collection by spreading questionnaires to 100 respondents. While based on simultant test with $\mathrm{f}$ test results showed that variables of servicescape and hedonic shoping value simultaneously significant effect on impulse buying. Based on partial test with t test showed that variables of service scape effect the significance of the impulse buying with a significance level of 0,000 . And hedonic shoping value has significane effect of the impulse buying with a significant level of 0,000 .

Keyword : Servicscape, Hedonic Shopping Value, Impulse Buying 


\section{PENDAHULUAN}

Di era globalisasi, persaingan ritel yang semakin ketat pada saat ini dikarenakan Indonesia sudah sepakat berada dalam MEA (Masyarakat Ekonomi Asean), dimana arus masuknya investor atau pekerja asing membuat daya tarik sendiri dalam perkembangan usaha. Meningkatnyajumlah gerai ritel modern di Indonesia dan juga perubahan sosial budaya masyarakat yang menunjukan semakin besarnya peluang bisnis ritel di Indonesia sekaligus juga menunjukkan semakin ketatnya persaingan di Industri ini.

Sebagian konsumen berpindah konsep belanja dari toko modern, kini ke toko tradisional. Hal ini merupakan solusi ketat yang terjadi di setiap keluarga. Keputusan solusi ketat ini dipahami sebagai akibat rentetan panjang kondisi krisis keuangan dunia. Berdasarkan penelitian ACNielsen, terdapat kesimpulan penjualan barang konsumen melalui toko tradisional melonjak sangat tinggi sebesar 19,6\%. Oleh karena itu hal ini merupakan sebuah ancaman toko modern yang sangat nyata.

\section{Identifikasi Masalah}

1. Tren perbelanjaan di Indonesia semakin impulse setiap tahunnya, mayoritas pembeli cenderung membeli sesuatu yang tidak direncanakan. Maka untuk menghadapi persaingan yang hiperkompetitif dalam mencari perhatian konsumen dengan mencari formulasi yang tepat.

2. Menciptakan pengaturan lingkungan fisik yang nyaman dan menarik akan memberi pengaruh terhadap lamanya waktu yang dihabiskan dalam berbelanja oleh konsumen, akibatnya dapat meningkatkan probabilitas terjadinya pembelian tidak terencana.

3. Strategi yang paling penting yang harus dilakukan oleh pemasar untuk menghadapi persaingan tersebut adalah dengan memiliki pengetahuan tentang perilaku belanja konsumen yang menjadi pasar sasaran di toko ritel modern.

\section{Rumusan Masalah}

Apakah terdapatpengaruh antara Lingkungan fisik dan Hedonic shopping value terhadap Pembelian tidak direncankan di Giant Express Cilegon?

\section{Tujuan Penelitian}

Untuk mengetahui pengaruh yang signifikan antara Lingkungan Fisik dan Hedonic shopping value terhadap Pembelian tidak direncanakan di Giant Express Cilegon.

\section{LANDASAN TEORI DAN PENGEMBANGAN HIPOTESIS}

\section{Pengertian Pemasaran}

Pemasaran adalah suatu proses sosial yang didalam nya individu dan kelompok mendapatkan apa yang mereka butuhkan dan inginkan dengan menciptakan, menawarkan, dan secara bebas mempertukarkan produk yang bernilai dengan pihak lain. (Philip Kotler, 2002:9).

\section{Manajemen Pemasaran}

Pada dasarnya manajemen terdiri dari planning, organizing, actuating dan controlling dari seluruh kegiatan yang akan dilakukan. Philip Kotler 2007:6) mengemukakan bahwa manajemen pemasaran sebagai seni dan ilmu memilih pasar sasaran dan mendapatkan, 
menjaga dan menumbuhkan pelanggan dengan menciptakan. Menyerahkan dan mengkomunikasikan nilai pelanggan yang unggul.

\section{Definisi Perilaku Konsumen}

Menurut Kotlerdan Keller (2009:166) Perilaku konsumen adalah studi tentang bagaimana individu, kelompok, dan organisasi memilih, membeli, menggunakan, dan bagaimana barang, jasa, ide, atau pengalaman untuk memuaskan kebutuhan dan keinginan mereka.

\section{Retail Modern}

Berbelanja di toko retail modern sudah menjadi bagian dari gaya hidup bagi masyarakat Indonesia. Hal ini karena terjadi nya perubahan gaya hidup masyarakat Indonesia yang didukung oleh meluasnya penggunaan kartu kredit dan perubahan formal berbelanja pada masyarkat Indonesia, yaitu berbelanja dengan kegiatan rekreasi, kelebihan yang di tawarkan oleh retail modern bukan hanya ketersediaan barang tetapi retail modern juga mampu memenuhi aspek psikologis konsumen. Misalnya menyangkut keamanan, kenyamanan, dan kebersihan. Hal ini dapat kita lihat di sebagian besar retail modern yang menyediakan berbagai outlet menarik dan tempat parkir yang luas dan gratis serta keamanan yang selalu berjaga 24 jam, dan dengan dilayani oleh pelayan yang cantik dan terdengar suara musik yang merdu membuat suasana berbelanja semakin terasa menarik.

Retail adalah suatu usaha yang kegiatannya menyangkut penjualan barang atau jasa secara langsung kepada konsumen untuk penggunaan pribadi dan nir-bisnis (Kotler dan Armstrong 2003:51).Daridefinisi tersebut kita dapat menyimpulkan bahwa retail adalah usaha bisnis di bidang penjualan barang retail sebagai semua kegiatan yang terlibat dalam penjualan atau jasa secara langsung kepada konsumen untuk digunakan secara pribadi dan bukan untuk penggunaan bisnis.

\section{Lingkungan Fisik}

Bitner (1992:58) lingkungan fisikadalah "The way the physical setting is created in organic nations has barely been tapped as a tangible organizational resource" artinya pengaturan lingkungan fisik diciptakan supaya mendukung layanan yangdiberikan oleh suatu organisasi.

Pemahaman mengenai lingkungan fisik sangat penting bagi pemasar, karena lingkungan fisik mempunyai beberapa peranan sekaligus (Tjiptono, 2008:87)yaitu:

a. Package, lingkungan fisik berperan untuk dapat "membungkus" atau "mengemas' jasa yang ditawarkan dan mengkomunikasikan citra yang ditawarkan oleh perusahaan jasa kepada konsumen nya.

b. Fasilitator, lingkungan fisik memainkan peran yang cukup signifikan, yaitu sebagai perantara hubungan antara persepsi konsumen dalam pengalaman sebenarnya yang dirasakan oleh konsumen didalam lingkungan fisik dan evaluasi akhir selama proses penghantaran jasa dan setelah konsumen selesai mengkonsumsi jasa.

c. Sosializer, desain lingkungan fisik juga berperan dalam proses sosialisasi melalui pengkonsumsian nilai-nilai, norma, perilaku, peran dan pola hubungan antara konsumen dengan karyawan.

d. Differentiaton, lingkungan fisik juga dapat digunakan untuk membedakan perusahaan dari para pesaingnya melalui gaya arsitektur untuk menyampaikan jenis layanan yang memberikan dan mengkomunikasikan tipe segmen pasar yang akan dilayani. 


\section{Dimensi Lingkungan Fisik}

Mudie dan Pirrie (2006:84) mengutip pendapat Bitner (1992:58) lingkungan fisikmemiliki dimensi kunci yang terdiri atas kondisi lingkungan (ambient conditions), tata letakruang dan fungsi (spatial layout and functionality), dan penggunaan tanda-tanda, simboldan artifak (the use of signs, symbols, and artefaks).

a. Ambient condition (kondisi lingkungan) merujuk kepada karakteristik latarbelakang yang tidak berwujud dari sebuah lingkungan. Ambient condition mempunyai beberapa sub yaitu: pencahayaan, temperature, kebisingan, music, warna, dan aroma.

b. Spatial layout and functionality (tata letak ruang dan fungsi nya), tata letak merupakan cara mengatur peralatan mesin, perlengkapan dan perabotan. Sedangkan fungsi merupakan kemampuan benda0benda tersebut untuk memfasilitasi pencapaian tujuan konsumen.

c. Sign, symbols, and artifacts (tanda,symbol, dan artifak), merupakan sinyal eksplisit dan implicit yang mengkomunikasikan sebuah tempat kepada konsumen. Tandatanda yang ditampilkan pada interior dan eksterior lingkungan jasa merupakan contoh komunikator eksplisit. Mereka dapat digunakan sebagai lebel (misal: nama perusahaan, nama departemen) untuk petunjuk arah (misal: pintu masuk atau pintu keluar) dan untuk mengkomunikasikan aturan-aturan perilaku (misal: dilarang meroko, anak anak harus disertai oleh orang dewasa). Artifak memberikan isyarat implicit kepada konsumen tentang makna tempat, norma-norma, dan harapan untuk berperilaku di tempat itu (misal: keberadaan karya seni pahat patung untuk memberitahu bahwa disini tempat makan atau tempat berbelanja).

\section{Hedonic Shopping Value}

Hedonic shopping value menurut Samuel (2005:144) mencerminkan instrument yang menyajikan secara langsung manfaat dari suatu pengalaman dalam melakukan pembelanjaan, seperti kesenangan-kesenangan dan hal-hal baru. Dalam penelitian menurut Arnold dan Reynolds (2003:77-95) dijelaskan bahwa secara motivasi hedonis merupakan suatu kegiatan pembelian yang didorong dengan perilaku yang berhubungan dengan panca indera, khayalan dan emosi yang menjadikan kesenangan dan kenikmatan materi sebagai tujuan utamaan hidup. Mereka juga menggolongkan motivasi hedonis ke dalam enam kategori, yaitu :

1) Adventure shopping

Adventure shopping mengarah pada petualangan pembelian.

2) Social shopping

Motivasi pembelian ini mengarah pada suasana kebersamaan konsumen, sahabat, atau pengunjung lain.

3) Gratification shopping

Perasaan tertentu, seperti rasa senang karena berhasil melakukan presentasi, atau tertekan karena sedang mengalami masalah.

4) Idea shopping

Mengarah pada motivasi seseorang untuk mengetahui tren, fashion, dan inovasi terbaru pada saat itu. 
5) Role shopping

Termotivasi melakukan pembelian untuk orang lain.

6) Value shopping

Mengarah pada motivasi pembelian karena suatu barang sedang dalam progam diskon atau promosi.

\section{Pembelian tidak direncanakan}

Mayoritas pembelian di pasar swalayan dilakukan dengan cara impulse, Menurut Utami (2010:46) pembelian tidak direncanakan adalah suatu desakan hati yang tiba-tiba dengan penuh kekuatan, bertahan dan tidak direncanakan untuk membeli sesuatu secara langsung dilokasi belanja, tanpa banyak memperhatikan akibatnya. Pembelian tidak direncanakanini memiliki satu atau lebih karakteristik, yaitu :

1. Spontanitas, pembelian ini tidak diharapkan dan memotivasi konsumen untuk membeli sekarang, sering sebagai respon terhadap stimulasi visual yang langsung ditempat penjualan.

2. Kekuatan,kompulsi, dan intensitas, mungkin ada motivasi untuk mengesampingkan semua yang lain dan bertindak dengan seketika.

3. Kegairahan dan stimulasi, desakan mendadak untuk membeli sering disertai dengan emosi yang dicirikan sebagai "menggairahkan" atau "liar".

4. Ketidakpedulian akan akibat, desakan untuk membeli dapat menjadi begitu sulit ditolak sehingga akibat uang mungkin negatif diabaikan.

Pembuatan keputusan dalam pembelian tidak direncakan dipengaruhi oleh masalah kognisi dan afeksi dalam diri seseorang, di mana segi afeksi lebih mengemuka dibanding sisi kognisi yang ada (Coley \& Burgess, 2003:284-285) yang lebih banyak dipengaruhi oleh stimuli eksternal berkaitan dengan faktor harga. Pembelian tidak direncanakan terdiri dari dua elemen, yaitu:

1. Afektif, yaitu proses psikologis dalam diri seseorang yang merujuk kepada emosi, perasaan maupun suasana hati (mood).

2. Kognitif, yaitu proses psikologis seseorang yang merujuk kepada struktur dan proses mental yang meliputi pemikiran, pemahaman dan penginterpretasian.

Dalam penelitian Manik Yistiani dkk(2012:139-149) faktor lain yang mempengaruhi pembelian tidak terencana yaitu faktor dari luar diri konsumen yang meliputi suasana dari lingkungan belanja itu sendiri. Pelanggan yang merasa nyaman dengan lingkungan toko ditambah dengan motivasi emosional maka akan memungkinkan meningkatnya pembelian secara tidak terencana dan terdapat empat indikator, yaitu :

1. Pembelian tidak direncanakan sebelumnya.

2. Pembelian tanpa berfikir akan akibat.

3. Pembelian diperngaruhi keadaan emosional.

4. Pembelian dipengaruhi penawaran menarik.

Dengan dasar penjelasan diatas maka pembelian tidak direncankan merupakan kegiatan untuk berbelanja tanpa control diri dengan sedikit atau tanpa pertingmbangan mendalam. 
Alasannya adalah pengalaman emosional yang lebih rasioal, karena nya pembelian pun dilakukan, sehingga kebanyakan pembelian dilakukan pada barang-barang yang tidak diperlukan.

Kategori pembelian tidak direncanakan dapat dibagi menjadi empat klasifikasi sebagai berikut :

1. Pure impulse, pembelian dilakukan murni tanpa rencana atau terkesan mendadak, biasa nya terjadi setelah melihat barang yang dipajang di toko dan muncul keinginan untuk memiliki nya saat itu juga.

2. Reminder impulse, pembelian dilakukan tanpa rencana setelah diingatkan ketika melihat iklan atau brosur yang ada di pusat perbelanjaan.

3. Suggestion impulse, pembelian ini dilakukan tanpa rencana pada saaat berbelanja dipusat perbelanjaan. Pembeli terpengaruh karena diyakini oleh penjuaal atau teman yang ditemui pada saat berbelanja.

4. Planned impulse, pembeli melakukan pembelian karena sebenar nya sudah direncanakan tapi karena barang yang dimaksud habis atau tidak sesuai dengan apa yag diinginkan maka pembelian dilakukan dengan mengambil jenis barang yang sama tetapi dengan merek atau ukuran yang berbeda.

\section{METODE PENELITIAN}

Penelitian ini adalah riset ini adalah korelasi (correlational study), penelitian korelasi adalah penelitian yang dirancang untuk menentukan tingkat hubungan variabel-variabel yang berbeda dalam suatu populasi. Penelitian yang digunakan adalah kuantitatif eksplanatori adalah suatu jenis penelitian yang sifatnya memberikan penjelasan tentang pengaruh antara variabel independen (Lingkungan fisik dan Hedonic shopping value) dengan variabel dependen (Pembelian tidak direncanakan).Pendekatan penelitian adalah sensus yang mengambil seluruh populasi yang menjadi sampel dan menggunakan kuesioner sebagai alat pengumpulan data jenis penelitian adalah deskriptif kuantitatif memiliki kejelasan unsur yang dirinci sejak awaal, langkah penelitian yang sistematif, menggunakan sampel yang hasil penelitiannya.

\section{Teknik Pengambilan Sampel}

Teknik pengambilan sampel menggunakan non probability sampling yaitu accidental sampling. Dalam non probability, setiap unsur dalam populasi tidak memiliki kesempatan atau peluang yang sama untuk dipilih sebagai sampel. Penelilitian unit sampling didasarkan pada pertimbangkan atau penilaian subjektif dan tidak menggunakan teori probability. Untuk lebih jelasnya dapat melihat gambar teknik sampling menurut Malhorta (2006) berikut ini : 


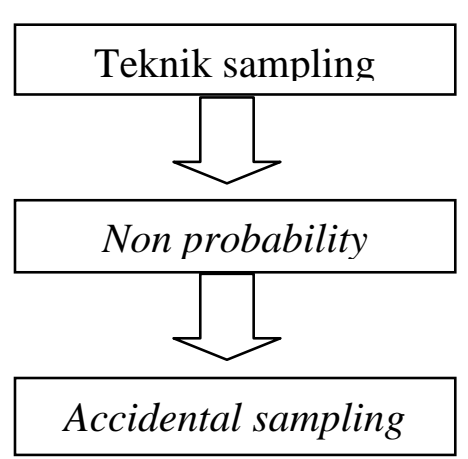

Gambar 3.1 teknik sampling

Sumber : Malhorta 2006

\section{Metode Analisis Data}

Data-data yang telah dikumpulkan melalui metode pengambilan data dapat dimanfaatkan sebagai dasar dalam pengambilan keputusan, namun sebelumnya data tersebut harus diolah dan dianalisis terlebih dahulu.

\section{Uji Hipotesis}

Pengujian terhadap masing-masing hipotesis yang diajukan dapat dilakukan dengan cara berikut :

Uji signifikansi (pengaruh nyata) variabel indenpenden $(X)$ terhadap variael dependen (Y) secara parsial dilakukan dengan menggunakan uji-t sementara pengujian secara bersama-sama dilakukan dengan uji-F pada level 5\% $(\alpha=0,05)$ (Ghozali, 2012).

\section{Uji Parsial (Uji t)}

Uji T digunakan untuk menguji hipotesis pengaruh variabel bebas (Lingkungan fisik dan Hedonic shopping value) terhadap variabel terikat (Pembelian tidak direncanakan) secara terpisah (parsial). Setelah melakukan uji koefisien regresi secara keseluruhan, maka langkah selanjutnya adalah menghitung koefisien regresi secara individu, dengan menggunakan uji t. Adapun hipotesis dalam uji ini adalah sebagai berikut:

Ho : $\beta_{1}=0$, i dimana $X_{1} X_{2}$ artinyal lingkungan fisik danHedonic shopping value secara parsial (sendiri-sendiri) tidak berpengaruh terhadap pembelian tidak direncanakan.

Ho : $\beta_{1} \neq 0$, i dimana $X_{1} X_{2}$ artinya lingkungan fisik dan Hedonic shopping valuesecara parsial(sendiri-sendiri) berpengaruh terhadap pembelian tidak direncanakan.

Dalam pengambilan keputusan :

Jika nilai $t_{\text {hitung }}>t_{\text {tabel }}$ maka $H_{o}$ ditolak sehingga lingkungan fisik dan Hedonic shopping value secara parsial (sendiri-sendiri) berpengaruh terhadap pembelian tidak direncanakan.

Jika nilai $t_{\text {hitung }}<t_{\text {tabel }}$ maka $H_{o}$ diterima lingkungan fisik danHedonic shopping value secara parsial (sendiri-sendiri) tidak berpengaruh terhadap pembelian tidak direncanakan. 


\section{Uji Simultan (Uji F)}

Uji F ini digunakan untuk mengetahui besarnya pengaruh variabel bebas (lingkungan fisik dan Hedonic shopping value) secara simultan atau keseluruhan, bersamaan terhadap variabel terikat (pembelian tidak direncanakan). Uji F diperuntukkan guna melakukan uji hipotesis koefisien regresi secara bersamaan (Pengaruh $\mathrm{X}_{1}$ dan $\mathrm{X}_{2}$ terhadap $\mathrm{Y}$ secara bersama-sama). Secara umum hipotesisnya dituliskan sebagai berikut:

Ho : $\beta_{1}=\beta_{2}=0$ artinya lingkungan fisik sdan hedonic shopping value secara bersamasama tidak berpengaruh terhadap pembelian tidak direncanakan.

H1: $\beta_{1}=\beta_{2} \neq 0$ artinya lingkungan fisik dan hedonic shopping value secara bersamasama berpengaruh terhadap pembelian tidak direncanakan.

Dasar pengambilan keputusan :

Jika nila $F_{\text {hitung }}>F_{\text {tabel }}$ maka $H_{o}$ ditolak lingkungan fisik dan Hedonic shopping value secara bersama-sama berpengaruh terhadap pembelian tidak direncanakan.

Jika nila $\mathrm{F}_{\text {hitung }}<\mathrm{F}_{\text {tabel }}$ maka $\mathrm{H}_{\mathrm{o}}$ diterima sehingga lingkungan fisik danHedonic shopping value secara bersama-sama tidak berpengaruh terhadap pembelian tidak direncanakan.

\section{HASIL ANALISIS DAN PEMBAHASAN}

Tanggapan Responden Pengaruh Lingkungan Fisik dan Hedonic Shopping Value Terhadap Pembelian Tidak Direncanakan.

\section{Tanggapan Responden Terhadap Lingkungan Fisik ( Variabel X1 ) di Giant Express Cilegon}

Untuk dapat mengetahui secara pasti tentang Lingkungan Fisik dapat ditinjau gambaran umum dari para responden diperoleh dari penyebaran kuesioner terhadap konsumen Giant Express Cilegon sebagai berikut :

Tabel. 1 Rekapitulasi Tanggapan Tentang Lingkungan Fisik (X1)

\begin{tabular}{|c|c|c|c|c|c|c|c|c|}
\hline \multirow{2}{*}{ No } & \multirow{2}{*}{ Pernyataan } & \multicolumn{5}{|c|}{ Bobot Tiap Jawaban } & \multirow{2}{*}{ skor } & \multirow{2}{*}{ Keterangan } \\
\hline & & 5 & 4 & 3 & 2 & 1 & & \\
\hline 1 & 1 & 17 & 47 & 35 & 1 & 0 & 380 & Tinggi \\
\hline 2 & 2 & 13 & 50 & 35 & 2 & 0 & 374 & Tinggi \\
\hline 3 & 3 & 17 & 51 & 31 & 1 & 0 & 384 & Tinggi \\
\hline 4 & 4 & 13 & 48 & 29 & 9 & 1 & 363 & Tinggi \\
\hline 5 & 5 & 20 & 40 & 28 & 11 & 1 & 367 & Tinggi \\
\hline 6 & 6 & 16 & 41 & 33 & 8 & 2 & 361 & Tinggi \\
\hline \multicolumn{2}{|c|}{ Jumlah } & & & & & & 2229 & \multirow{2}{*}{ Tinggi } \\
\hline \multicolumn{6}{|c|}{ Nilai Rata - rata Jawaban Responden } & & 247,67 & \\
\hline
\end{tabular}

Sumber : Hasil Kuesioner 
Berdasarkan penggolongan yang menggunakan pembobotan skala likert, jumlah rata - rata 247,67 tersebut tergolong kedalam nilai interval pengaruh lingkungan fisik di Giant Express Cilegon dengan nilai 340 - 420 dari semua nilai kuesioner termasuk dalam kategori "TINGGI".

2. Tanggapan Responden Terhadap Hedonic Shopping Value di Giant Express Cilegon

Tabel. 2 Rekapitulasi Tanggapan Tentang Hedonic Shopping Value (X2)

\begin{tabular}{|c|c|c|c|c|c|c|c|c|}
\hline \multirow{2}{*}{ No } & \multirow{2}{*}{ Pernyataan } & \multicolumn{5}{|c|}{ Bobot Tiap Jawaban } & \multirow{2}{*}{ skor } & \multirow{2}{*}{ Keterangan } \\
\hline & & 5 & 4 & 3 & 2 & 1 & & \\
\hline 1 & 1 & 21 & 52 & 25 & 2 & 0 & 392 & Tinggi \\
\hline 2 & 2 & 13 & 34 & 50 & 3 & 0 & 357 & Tinggi \\
\hline 3 & 3 & 15 & 47 & 36 & 2 & 0 & 375 & Tinggi \\
\hline 4 & 4 & 16 & 49 & 34 & 1 & 0 & 380 & Tinggi \\
\hline 5 & 5 & 18 & 50 & 29 & 3 & 0 & 383 & Tinggi \\
\hline 6 & 6 & 20 & 49 & 28 & 3 & 0 & 386 & Tinggi \\
\hline \multicolumn{2}{|c|}{ Jumlah } & & & & & & 2273 & \multirow{2}{*}{ Tinggi } \\
\hline \multicolumn{6}{|c|}{ Nilai Rata - rata J } & & 252,5556 & \\
\hline
\end{tabular}

Sumber : Hasil Kuesioner

Berdasarkan penggolongan yang menggunakan pembobotan skala likert, jumlah rata - rata 252,56 tersebut tergolong kedalam nilai interval pengaruh hedonic shopping value di Giant Express Cilegon dengan nilai 340 - 420 dari semua nilai kuesioner termasuk dalam kategori "TINGGI".

3. Tanggapan Responden Terhadap Pembelian Tidak Direncanakan ( Y ) di Giant Express Cilegon

Tabel 3. Rekapitulasi Tanggapan Tentang Pembelian Tidak Direncanakan (Y)

\begin{tabular}{|c|c|c|c|c|c|c|c|c|}
\hline \multirow{2}{*}{ No } & \multirow{2}{*}{ Pernyataan } & \multicolumn{5}{|c|}{ Bobot Tiap Jawaban } & \multirow{2}{*}{ skor } & \multirow{2}{*}{ Keterangan } \\
\hline & & 5 & 4 & 3 & 2 & 1 & & \\
\hline 1 & 1 & 22 & 41 & 27 & 9 & 1 & 374 & Tinggi \\
\hline 2 & 2 & 20 & 39 & 34 & 6 & 1 & 371 & Tinggi \\
\hline 3 & 3 & 18 & 51 & 28 & 3 & 0 & 384 & Tinggi \\
\hline 4 & 4 & 13 & 46 & 36 & 5 & 0 & 367 & Tinggi \\
\hline 5 & 5 & 25 & 50 & 23 & 2 & 0 & 398 & Tinggi \\
\hline 6 & 6 & 11 & 36 & 50 & 3 & 0 & 355 & Tinggi \\
\hline 7 & 7 & 18 & 52 & 27 & 3 & 0 & 385 & Tinggi \\
\hline 7 & 8 & 21 & 49 & 27 & 3 & 0 & 388 & Tinggi \\
\hline \multicolumn{2}{|c|}{ Jumlah } & & & & & & 3022 & \multirow{2}{*}{ Tinggi } \\
\hline \multicolumn{6}{|c|}{ Nilai Rata - rata Jawaban Responden } & & 335,78 & \\
\hline
\end{tabular}

mber : Hasil Kuesioner 
Berdasarkan penggolongan yang menggunakan pembobotan skala likert, jumlah rata - rata 335,78 tersebut tergolong kedalam nilai interval pengaruh hedonic shopping value di Giant Express Cilegon dengan nilai 340 - 420 dari semua nilai kuesioner termasuk dalam kategori "TINGGI".

\section{Analisis Penelitian}

1. Analisis Regresi Linier Berganda

Tabel 4. pengaruh Lingkungan Fisik (X1), Hedonic Shopping

Coefficients $^{\mathrm{a}}$

\begin{tabular}{|c|c|c|c|c|c|}
\hline \multirow[t]{2}{*}{ Model } & \multicolumn{2}{|c|}{ Unstandardized Coefficients } & \multirow{2}{*}{$\begin{array}{c}\begin{array}{c}\text { Standardized } \\
\text { Coefficients }\end{array} \\
\text { Beta }\end{array}$} & \multirow[t]{2}{*}{$\mathrm{t}$} & \multirow[t]{2}{*}{ Sig. } \\
\hline & $B$ & Std. Error & & & \\
\hline (Constant) & 1,703 & 1,511 & & 1,127 & 263 \\
\hline 1 Tot_x1 & ,321 & ,061 & 311 & 5,228 & ,000 \\
\hline Tot_x2 & 770 & ,069 & ,664 & 11,156 &, 000 \\
\hline
\end{tabular}

a. Dependent Variable: TotNew_Y

Sumber : Hasil Pengolahan Data SPSS V.20

Berdasarkan hasil perhitungan pada tabel diatas, diperoleh bentuk persamaan regresi sebagai berikut $: \mathrm{Y}=1,703+0,321\left(\mathrm{X}_{1}\right)+0,770\left(\mathrm{X}_{2}\right)+$ ePersamaan regresi tersebut mempunyai interpretasi sebagai berikut : Nilai koefisien regresi pada variabel bebasnya menggambarkan apabila diperkirakan variabel bebasnya naik sebesar satu unit dan nilai variabel bebas lainnya diperkirakan konstan atau sama dengan nol, maka nilai variabel terikat diperkirakan bisa naik atau bisa turun sesuai dengan tanda koefisien regresi variabel bebasnya.Dari persamaan regresi linier berganda diatas diperoleh nilai konstanta sebesar 1,703. Artinya, jika variabel Pembelian Tidak Direncanakan (Y) tidak dipengaruhi oleh variabel bebasnya (Lingkungan Fisik dan Hedonic Shopping Value), maka besarnya rata-rata nilai Pembelian Tidak Direncanakan (Y) bernilai 1,703 persen.Tanda koefisien regresi variabel bebas menunjukkan arah hubungan dari variabel yang bersangkutan dengan Pembelian Tidak Direncanakan (Y). Koefisien regresi untuk variabel bebas $\mathrm{X}_{1}$ bernilai positif, menunjukkan adanya hubungan searah antara Lingkungan Fisik $\left(\mathrm{X}_{1}\right)$ dan Pembelian Tidak Direncanakan (Y). Koefisien regresi variabel $\mathrm{X}_{1}$ sebesar 0,321 mengandung arti untuk setiap kenaikan nilai Lingkugan Fisik $\left(\mathrm{X}_{1}\right)$ sebesar satu persen akan menyebabkan meningkatnya Pembelian Tidak Direncanakan (Y) sebesar 0,321 persen.

Tanda koefisien regresi variabel bebas menunjukkan arah hubungan dari variabel yang bersangkutan dengan Pembelian Tidak Direncanakan (Y). Koefisien regresi untuk variabel bebas $\mathrm{X}_{2}$ bernilai positif, menunjukkan adanya hubungan satu arah antara Hedonic Shopping Value $\left(\mathrm{X}_{2}\right)$ dan Pembelian Tidak Direncanakan (Y). Koefisien regresi variabel $\mathrm{X}_{2}$ sebesar 0,770 mengandung arti untuk setiap kenaikan nilai Hedonic Shopping Value $\left(\mathrm{X}_{2}\right)$ sebesar satu persen akan menyebabkan meningkatnya Pembelian Tidak Direncanakan (Y) sebesar 0,770 persen.

\section{Koefisien Determinasi $\left(\mathbf{R}^{2}\right)$}


Koefisien determinasi menunjukkan berapa persen dari variasi (naik turunnya) variabel dependent dapat diterangkan atau di jelaskan oleh variasi variabel independen, koefisien determinasi merupakan dari koefisien korelasi dan dinyatakan dalam bentuk persen.

Tabel 5. Hasil Uji Koefisien Determinasi

Model Summary

\begin{tabular}{|r|r|r|r|r|}
\hline Model & $\mathrm{R}$ & $\mathrm{R}$ Square & Adjusted R Square & $\begin{array}{c}\text { Std. Error of the } \\
\text { Estimate }\end{array}$ \\
\hline 1 &, $859^{\mathrm{a}}$ &, 737 &, 732 & 1,70784 \\
\hline
\end{tabular}

a. Predictors: (Constant), Tot_x2, Tot_x1

b. Dependent Variable: TotNew_Y

Sumber : Hasil Pengolahan Data SPSS V.20

Berdasarkan tabel di atas diperoleh nilai koefisien determinasi berganda $\left(\mathrm{R}^{2}\right) r$ square sebesar 0,737. Hal ini dapat di artikan bahwa besarnya kontribusi Lingkungan Fisik $\left(\mathrm{X}_{1}\right)$ dan Hedonic Shopping Value $\left(\mathrm{X}_{2}\right)$ mempengaruhi sebesar $73,7 \%$ terhadap Pembelian Tidak Direncanakan (Y) sedangkan sisanya sebesar 26,3\% dipengaruhi oleh faktor lain.

\section{Uji Hipotesis}

\section{Parsial}

Pengujian ini bertujuan untuk menguji pengaruh variabel bebas (Lingkungan Fisik dan Hedonic Shopping Value) berpengaruh signifikan atau tidak, terhadap variabel terikatPembelian Tidak Direncanakan (Y) dengan tingkat signifikan $\alpha=5 \%$ secara parsial. Berikut hasil pengujian hipotesis uji t:

\section{Tabel 6. Hasil Uji Hipotesis Parsial}

\begin{tabular}{|c|c|c|c|c|c|c|}
\hline \multirow{2}{*}{\multicolumn{2}{|c|}{ Model }} & \multicolumn{2}{|c|}{ Unstandardized Coefficients } & \multirow{2}{*}{$\begin{array}{c}\begin{array}{c}\text { Standardized } \\
\text { Coefficients }\end{array} \\
\text { Beta }\end{array}$} & \multirow[t]{2}{*}{$\mathrm{t}$} & \multirow[t]{2}{*}{ Sig. } \\
\hline & & $\mathrm{B}$ & Std. Error & & & \\
\hline \multirow{3}{*}{1} & (Constant) & 1,703 & 1,511 & & 1,127 & ,263 \\
\hline & Tot_x1 & ,321 &, 061 & ,311 & 5,228 &, 000 \\
\hline & Tot_x2 & ,770 & ,069 & ,664 & 11,156 & ,000 \\
\hline
\end{tabular}

a. Dependent Variable: TotNew_Y

Sumber : Hasil Pengolahan Data SPSS V.20

Berdasarkan Tabel diatas dapat dilihat bahwa hasil perhitungan koefisien regresi dengan Uji t adalah sebagai berikut :

Variabel Lingkungan Fisik (X1) memiliki pengaruh positif dan signifikan terhadap Pembelian Tidak Direncanakan (Y) dengan nilai regresi 0,321 nilai $\mathrm{t}$ hitung $=5,228$ 
dengan tingkat signifikansi 0,000. "Lingkungan Fisik berpengaruh terhadap Pembelian Tidak Direncanakan".

Untuk variabel Hedonic Shopping Value (X2) terhadap Pembelian Tidak Direncanakan (Y), berdasarkan tabel didapat nilai t tabel 1,984, kemudian nilai tersebut dibandingkan dengan nilai dengan 0,05 derajat kebebasan $(\mathrm{dk}) \mathrm{n}-2$ atau $100-2=98$. Nilai t tabel sebesar 1,984 dengan uji dua pihak maka $t$ hitung $(11,156)>t$ tabel $(1,984)$, ini artinya. Ho ditolak , Ha diterima. Hipotesis terbuka ada pengaruh yang signifikan Hedonic Shopping Value terhadap Pembelian Tidak Direncanakan.

\section{Uji Simultan ( Uji F )}

Uji ini menggunakan uji $\mathrm{F}$ untuk membuktikan apakah variabel Lingkungan Fisik $\left(\mathrm{X}_{1}\right)$ dan Hedonic Shopping Value $\left(\mathrm{X}_{2}\right)$ secara simultan mempunyai pengaruh terhadap Pembelian Tidak Direncanakan (Y), maka dilakukan uji F dengan menggunakan SPSS V.20 adalah sebagai berikut :

\section{Tabel 7. Hasil Uji Hipotesis Simultan}

\begin{tabular}{ll|r|r|r|r|r|}
\hline Model & Sum of Squares & df & Mean Square & F & Sig. \\
\hline & Regression & 794,390 & 2 & 397,195 & 136,179 &, $000^{\text {b }}$ \\
1 & Residual & 282,920 & 97 & 2,917 & & \\
Total & 1077,310 & 99 & & & \\
\hline
\end{tabular}
a. Dependent Variable: TotNew_Y
b. Predictors: (Constant), Tot_x2, Tot_x1

\section{Sumber : Hasil Pengolahan Data SPSS V.20}

Dengan tingkat keyakinan atau $\alpha=0,05$ diperoleh nilai $\mathrm{F}$ tabel $=3,09$ bandingkan dengan nilai $\mathrm{F}$ hitung $=136,179$ yang diperoleh untuk menentukan apakah pengaruhnya signifikan atau tidak, (136,179>3,09 . Pengujian pengaruh variabel bebas secara bersama - sama terhadap variabel terikatnya dilakukan dengan menggunakan uji F. Hasil perhitungan statistik menunjukkan nilai $\mathrm{F}$ hitung $=136,179>\mathrm{F}$ tabel $=3,09$ dengan signifikansi sebesar $0,000<0,05$. Hal ini berarti bahwa secara bersama - sama Lingkungan Fisik dan Hedonic Shopping Value mempunyai pengaruh yang signifikan terhadap Pembelian Tidak Direncanakan.

\section{PENUTUP}

\section{Simpulan}

Berdasarkan hasil analisis dan pembahasan pada pengaruh Lingkungan Fisik dan Hedonic Shopping Value terhadap Pembelian Tidak Direncanakan di Giant Express Cilegon, penulis menarik kesimpulan sebagai berikut :

1. Penelitian ini berhasil membuktikan adanya pengaruh Lingkungan Fisik $\left(\mathrm{X}_{1}\right)$ terhadap Pembelian Tidak Direncanakan (Y) di Giant Express Cilegon. Hasil penilaian responden terhadap Lingkungan Fisik $\left(\mathrm{X}_{1}\right)$ Giant Express Cilegon berada pada kriteria yang tinggi. 
2. Penelitian ini berhasil membuktikan adanya pengaruh Hedonic Shopping Value $\left(\mathrm{X}_{2}\right)$ terhadap Pembelian Tidak Direncanakan (Y) di Giant Express Cilegon. Hasil penilaian responden terhadap Hedonic Shopping Value $\left(\mathrm{X}_{2}\right)$ Giant Express Cilegon berada pada kriteria yang tinggi.

3. Dari hasil uji statistic penulis menarik kesimpulan adanya pengaruh secara simultan dari variabel Lingkungan Fisik $\left(\mathrm{X}_{1}\right)$ dan Hedonic Shopping Value $\left(\mathrm{X}_{2}\right)$ terhadap Pembelian Tidak Direncanakan (Y).

4. Berdasarkan Coefficients Betta Standard penulis menyimpulkan bahwa pengaruh Hedonic Shopping Value $\left(\mathrm{X}_{2}\right)$ terhadap Pembelian Tidak Direncanakan (Y) lebih besar dibandingkan dengan Lingkungan Fisik $\left(\mathrm{X}_{1}\right)$ terhadap Pembelian Tidak Direncanakan (Y).

\section{DAFTAR PUSTAKA}

Armstrong, dan Kotler 2003, Dasar-dasar Pemasaran, Jilid 1, Edisi Kesembilan, Jakarta : Penerbit PT. Indeks Gramedia.

Ghozali, Imam. 2009. Aplikasi Analisis Multivariate Dengan Progam SPSS.

Semarang : Badan Penerbit Undip

Kotler, Philip. 2001.Manajemen Pemasaran di Indonesia Jakarta Salemba Empat.

Kotler, Philip. 2002. Manajemen Pemasaran : Analisis, Perencanaan,Implementasi dan Kontrol,terj : Hendra Teguh dan Ronny AntoniusRusly, Edisi 9, Jilid 1 dan 2, Jakarta. PT Prenhalindo.

Kotler dan Keller. 2009. Manajemen Pemasaran, Jilid I, Edisi ke 13 Jakarta: Erlangga.

Bitner, Mary Jo, April 1992 Vol. 56, No. 2 , Lingkungan fisik: The Impact of Physical Surroundings on Customers and Employees.

Mudie, Peter And Angela Pirrie. (2006:84). Service Marketing Management. Third edition. Elsevier Ltd.

Samuel, H. 2005, Respon Lingkungan Berbelanja Sebagai Stimulus Pembelian Tidak Terencana Pada Toko Serba Ada (Toserba) Jurnal manajemen dan kewirausahaan, Vol. 7 No. 2, pp. 152-170.

Arnold, M. J. \& Reynolds, K. E. (2003).Hedonic shopping motivations.JournalofRetailing, 77-95

Utami, Christina Whidya. 2010. Manajemen Ritel : Strategi dan Implementasi Operasional Bisnis Ritel Modern Di Indonesia. Jakarta : Salemba Empat.

Coley, A. and Burgess, B. 2003. Gender differences in cognitive and affective impulse buying, Journalof Fashion Marketing andManagement Vol. 7 No.3, pp. 282- 295.

Malhorta, Naresh K. 2006. Riset Pemasaran : Pendekatan Terapan Jilid 2.Jakarta ： PT. Indeks

Tjiptono, Fandy. 2008. Strategi Pemasaran, Edisi Ketiga. Andi, Yogyakarta

Yistiani, Ni Nyoman Manik dkk. 2012. Pengaruh atmosfer Gerai dan pelayanan Ritel terhadap nilai Hedonik dan pembelian impulsif pelanggan Matahari Department Store Duta Plaza di Denpasar, Jurnal Manajemen, Startegi Bisnis dan Kewirausahaan, Vol 6 No 2 